\title{
Leukotriene receptor antagonists and biosynthesis inhibitors: potential breakthrough in asthma therapy
}

\author{
K.F. Chung
}

\begin{abstract}
Leukotriene receptor antagonists and biosynthesis inhibitors: potential breakthrough in asthma therapy. K.F. Chung. CERS Journals Ltd 1995.

ABSTRACT: Cysteinyl leukotrienes are potent bronchoconstrictors, inducers of airway microvascular leakage and oedema, and of mucus secretion, in addition to causing an eosinophilic airway infiltration. Increased urinary excretion of the cysteinyl leukotriene $\mathrm{E}_{4}\left(\mathrm{LTE}_{4}\right)$ has been demonstrated following allergen challenge and during acute asthma attacks.

Strategies for inhibition of cysteinyl leukotriene effects include antagonism of cysteinyl leukotriene receptors and inhibition of 5-lipoxygenase activity. In experimental challenge studies in asthmatic patients, these compounds can inhibit bronchoconstriction in response to exercise, aspirin and allergen. Results from clinical studies using receptor antagonists, such as ICI 204,219 and MK-571, and synthesis inhibitors, such as zileuton, demonstrate beneficial effects, with improvement in symptoms and forced expiratory volume in one second (FEV1), and a reduction in the use of $\beta_{2}$-adrenergic relief medication. Further studies are needed to clarify the exact mechanisms by which these compounds provide beneficial effects.

Cysteinyl leukotrienes are important mediators of asthma, and inhibition of their effects may represent a potential breakthrough in the therapy of asthma. Eur Respir J., 1995, 8, 1203-1213.
\end{abstract}

Dept of Thoracic Medicine, National Heart \& Lung Institute, Royal Brompton National Heart \& Lung Hospital, London, UK.

Correspondence: K F. Chung Dept of Thoracic Medicine

National Heart \& Lung Institute

Dovehouse St

London SW3 6LY

UK

\section{Keywords: Asthma}

bronchial hyperresponsiveness

cysteinyl leukotrienes

cysteinyl leukotriene receptor antagonists 5-lipoxygenase-activating protein inhibitors 5-lipoxygenase inhibitors

Received: June 271994

Accepted after revision February 261995
In recent years, there have been major advances in asthma both in the understanding of the pathophysiological processes in the airways and in the effective use of anti-inflammatory therapy [1,2]. Examination of bronchial mucosal biopsies obtained from the proximal large airways reveals a cellular infiltrate typically of eosinophils and lymphocytes, and epithelial damage and desquamation [3], with the expression of several cytokines, such as interleukins (IL-) 3, 4 and 5, and granulocytemacrophage colony stimulating factor (GM-CSF), particularly by lymphocytes and other cells types [4-6]. Several mediators, such as histamine, cysteinyl leukotrienes, kinins, and eosinophil products such as eosinophil cationic protein (ECP), have been detected in the asthmatic airway. Priming for release of mediators, in particular cysteinyl leukotrienes, especially from the eosinophil, may occur [7]. Mediators may act on target cells within the airways to induce features typical of asthma, such as bronchoconstriction, mucus plugging, airway wall oedema through microvascular leakage, eosinophil infiltration and bronchial hyperresponsiveness [8].

Although many mediators are likely to play a role in inducing these features, there is now compelling evidence for an important role for cysteinyl leukotrienes in asthma. This will be reviewed and the potential therapeutic importance of inhibiting the effects of leukotrienes in asthma will be discussed.

\section{Generation of leukotrienes (fig. 1)}

Leukotrienes are synthesized from arachidonic acid, a normal constituent of the phospholipid bilayer, which is liberated by the action of phospholipases in responses to various stimuli. Leukotrienes are formed by the activation of 5-lipoxygenase (5-LO) enzyme on arachidonic acid to form an unstable intermediate, 5-hydroperoxyeicosatetraenoic acid (5-HPETE) which is converted to epoxide leukotriene (LT) $\mathrm{A}_{4}$ [9]. 5-LO is a member of a family of lipoxygenases, and is an iron-containing enzyme consisting of 673 amino acids, which is dependent on $\mathrm{Ca}^{++}$, adenosine triphosphate and several cofactors for maximal activity [10]. 5-LO translocates from the cytosol to the nuclear cell membrane to initiate leukotriene biosynthesis. 5-HPETE is formed through the action of 5-LO and the 5-lipoxygenase-activating protein (FLAP), a nuclear membrane protein to which 5-LO binds to make a stable complex [11].

$\mathrm{LTA}_{4}$ is the pivotal intermediate from which all other leukotrienes are synthesized. LTA $_{4}$ hydrolase is a zinccontaining cytosolic metalloproteinase possessing intrisic aminopeptidase activity [12], with considerable homology to the aminopeptidase $\mathrm{N}$ family of enzymes. $\mathrm{LTA}_{4}$ enzymatic activity can be inhibited by metallohydrolase inhibitors, such as bestatin. LTA $_{4}$ is unstable and may be hydrolysed to the dihydroxyacid $\mathrm{LTB}_{4}$ by $\mathrm{LTA}_{4}$ 


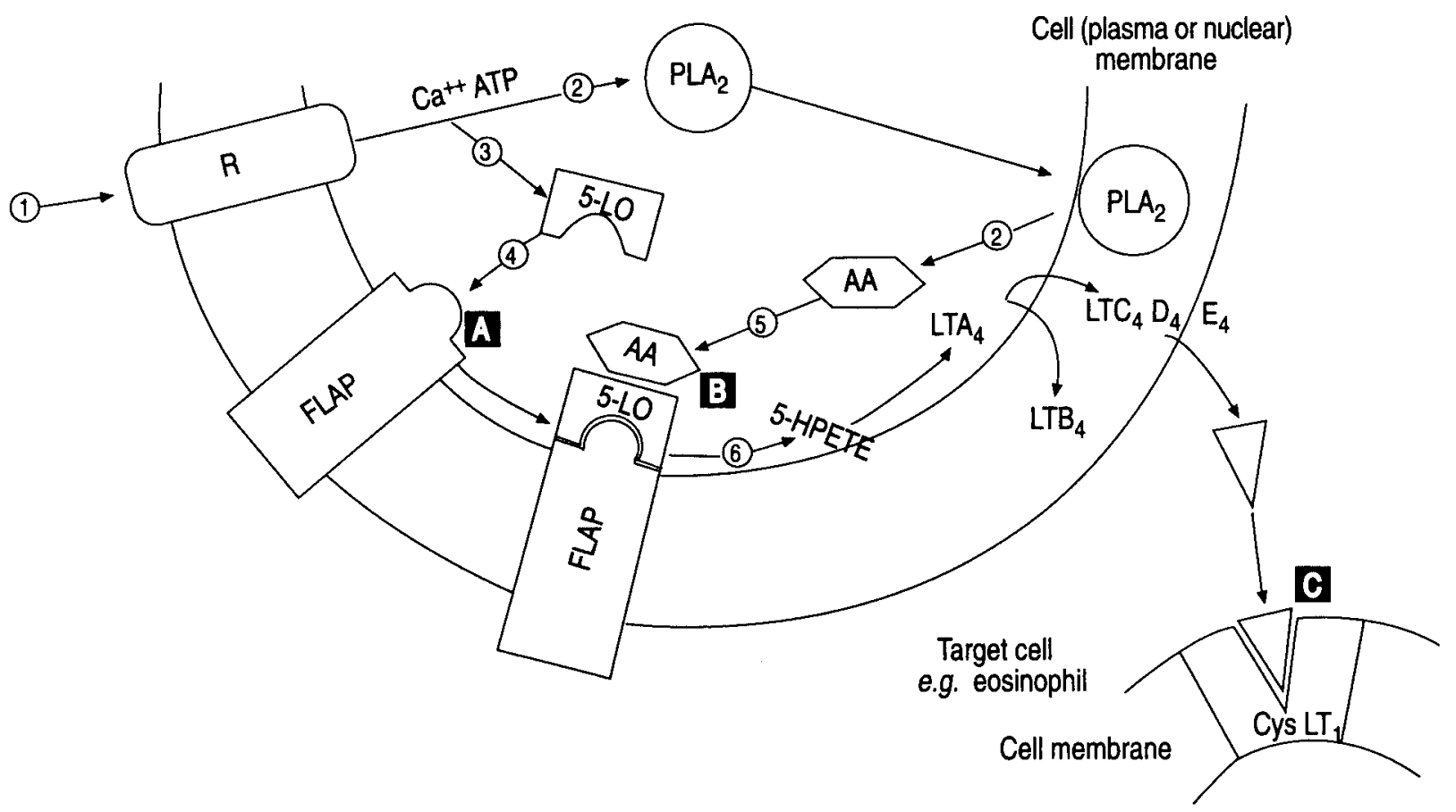

Fig. 1. - Proposed mechanism for the involvement of 5-LO and FLAP in the regulation of cellular leukotriene biosynthesis, and for various ways of inhibiting the effects of cysteinyl-leukotrienes. An inflammatory stimulus (R) leads to receptor-mediated intracellular influx of calcium $\left(\mathrm{Ca}^{++}\right)$ions (1), altowing cytosolic PLA 2 and 5-LO to translocate from the cytosol to the cell membrane (2) and (3). 5-LO binds to FLAP in the cell membrane to make a stable complex (4). PLA 2 cleaves AA from membrane phospholipids, and AA is converted by 5-LO in the presenc of FLAP to 5-HPETE (5) and (6). 5-HPETE is converted by 5-LO to LTA $_{4}$ which is converted by LTA $_{4}$ hydrolase to LTB L $_{4}$, or by LTC 4 synthas to $\mathrm{LTC}_{4}$, and subsequently to $\mathrm{LTD}_{4}$ and $\mathrm{LTE}_{4}$. Three sites of action for drugs are illustrated: A FLAP inhibitors which prevent 5-LO binding with FLAP; B 5-LO inhibitors which inhibits 5-LO activity and C cysteinyl-leukotriene receptor antagonists which inhibit the effects of cysteinylleukotrienes on other cells. R: receptor; ATP: adenosine triphosphate; PLA 2 : phospholipase $\mathrm{A}_{2}$; FLAP: 5-lipoxygenase-activating protein; 5-LO: 5-lipoxygenase; AA: arachidonic acid; 5-HPETE: 5-hydroperoxy-eicosatetraenoic acid; LT: leukotriene; CysLT ${ }_{1}$ : cysteinyl leukotriene receptor.

hydrolase, or glutathione is incorporated to form the peptidoleukotriene $\mathrm{LTC}_{4}$ by the enzyme $\mathrm{LTC}_{4}$ synthase. $\mathrm{LTC}_{4}$ synthase has been recognized as an $18 \mathrm{kDa}$ integral microsomal membrane protein and has recently been cloned [13]. The nucleotide and deduced amino acid sequences of its complementary deoxyribonucleic acid (cDNA) show no significant homology to glutathione $S$ transferases but share amino acid identity with FLAP [13]. Interestingly, MK-886, a FLAP inhibitor, inhibits $\mathrm{LTC}_{4}$ synthase activity.

The subsequent conversion of $\mathrm{LTC}_{4}$ to $\mathrm{LTD}_{4}$ a cysteinyl glycinyl derivative, is via the action of $\alpha$-glutamyl transpeptidase. $\mathrm{LTD}_{4}$ is further metabolized to the cysteinyl derivative, $\mathrm{LTE}_{4}$, by the action of a dipeptidase. Leukotrienes are rapidly metabolized and removed from the circulation. Peptidoleukotrienes undergo oxidation, resulting in biliary and urinary elimination of biologically less active and inactive metabolites. $\mathrm{LTE}_{4}$ is an important urinary metabolite that can be used to monitor the production of leukotrienes in man $[14,15]$.

The location of leukotriene synthesis is determined by the cellular distribution of the enzymes controlling each step of the pathway. The distribution of 5-lipoxygenase is limited to myeloid cells, including neutrophils, eosinophils, monocytes, macrophages, mast cells and basophils. LTC $_{4}$ synthase has been identified not only in mast cells and eosinophils but also in endothelial cells and platelets. $\mathrm{LTA}_{4}$ hydrolase has been found in human plasma, human erythrocytes, inflammatory cells, bronchoalveolar lavage fluid and airway epithelial cells. Because these enzymes are distributed among different cell types, various inflammatory cells, in concert with noninflammatory cells, such as endothelial cells or epithelial cells, can participate in the transcellular synthesis of leukotrienes [16, 17]. Monocytes and macrophages release both $\mathrm{LTB}_{4}$ and $\mathrm{LTD}_{4}$ after stimulation, while most other cells produce significant quantities of either $\mathrm{LTB}_{4}$ or $\mathrm{LTC}_{4}$ but not both. Cellular sources of cysteinyl leukotrienes include mast cells, macrophages and eosinophils. The predominant product of 5-LO eosinophil is $\mathrm{LTC}_{4}$ rather than $\mathrm{LTD}_{4}$, and cytokines such as IL-3, IL-5 and GM-CSF, which have been localized in asthmatic airways [4], are capable of enhancing leukotriene $\left(\mathrm{LTC}_{4}\right)$ synthesis $[18,19]$.

\section{Actions of leukotrienes relevant to asthma}

In in vitro and in vivo studies on human isolated bronchus, and in normal or asthmatic subjects following aerosol administration, respectively, $\mathrm{LTC}_{4}$ and $\mathrm{LTD}_{4}$ are approximately 1,000 times more potent than histamine in contracting human isolated bronchus [20-23]. Both large and small airways of normal and asthmatic patients are constricted by cysteinyl leukotrienes [22, 23]. Inhaled $\mathrm{LTC}_{4}$ and $\mathrm{LTD}_{4}$ are 1,000-5,000 times more potent than histamine, with a long duration of action [22, 24]. 
Although $\mathrm{LTE}_{4}$ is equipotent with $\mathrm{LTC}_{4}$ and $\mathrm{LTD}_{4}$ on isolated human bronchi, in vivo $\mathrm{LTE}_{4}$ is approximately one tenth as potent as LTD, but with a longer duration of action [25].

$\mathrm{LTC}_{4}$ and $\mathrm{LTD}_{4}$ are also potent stimulants of mucous glycoproteins from human airways in vitro $[26,27]$. In vivo, they enhance secretion of mucus [28], and stimulate secretion of chloride across the epithelium in dog trachea [29]. $\mathrm{LTC}_{4}, \mathrm{D}_{4}$ and $\mathrm{E}_{4}$ cause vascoconstriction and increase microvascular permeability in the airways of guinea-pigs [30, 31], being at least 100-1,000 times more active than histamine. In human skin, $\mathrm{LTC}_{4}$ and $\mathrm{LTD}_{4}$ are potent vasodilators, producing wheal and flare responses at low concentrations [32, 33]. Maximal airway narrowing induced by methacholine is augmented by $\mathrm{LTD}_{4}$ in normal subjects, an effect attributed to induction of airway oedema [34]. Inhalation of $\mathrm{LTE}_{4}$ by asthmatic subjects led to an increase in the number of eosinophils, and to a lesser extent of neutrophils, in bronchial mucosal biopsies $4 \mathrm{~h}$ after inhalation [35].

\section{Production of leukotrienes in asthma}

Increased production of leukotrienes can be demonstrated in asthmatic patients. Measurement of $\mathrm{LTE}_{4}$ excretion in urine is a convenient method for examining leukotriene production in vivo. Thus, increased urinary leukotrienes have been demonstrated following allergen challenge, during acute asthma, and aspirininduced asthma [36-41]. However, no increase in $\mathrm{LTE}_{4}$ excretion was shown after exercise-induced asthma [42], despite the fact that leukotriene antagonists inhibit this response [43]. Raised levels of leukotrienes, particularly $\mathrm{LTE}_{4}$ have been found in bronchoalveolar lavage fluid of asthmatic volunteers [44-46], with further increases after endobronchial allergen challenge [47].

\section{Strategies for inhibition of leukotriene effects}

In view of the properties of cysteinyl leukotrienes in mimicking several features of asthma, and of the strong evidence for their production in asthma, it was reasonable to hypothesize that inhibition of leukotriene effects would provide clinical benefit. Two basic modes of action are available for inhibition of leukotriene effects: 1) inhibition of synthesis; and 2) antagonism of leukotriene receptors [48] (fig. 1). Many different approaches are available for inhibiting leukotriene synthesis, including antagonism of FLAP, iron chelation, redox-activity, and inhibition of 5-LO active site. Inhibitors of 5-LO have the added advantage of also preventing the synthesis of $\mathrm{LTB}_{4}$ in addition to that of cysteinyl leukotrienes. Antagonism of leukotriene receptors is mainly achieved by using specific cysteinyl leukotriene receptor antagonists and blocking the actions of cysteinyl leukotrienes.

\section{Inhibitors of 5-lipoxygenase}

Inhibitors of 5-lipoxygenase reactions can act through a number of mechanisms, which include trapping of rad- ical intermediates, chelation or reduction of iron, reversible binding at either an active or a regulatory site, as well as combinations of these mechanisms.

Direct inhibition of 5-LO, partly through an iron-catalysed redox mechanism, has been achieved with compounds such as benzofurans (L-670,630 and L-650,224), hydroxamates (BWA4C), N-hydroxyurea derivatives (A64077 or zileuton) and indazolinones (ICI 207,968), with good selectivity and potency [49]. ICI 207,968 and BWA4C, which are orally active, produced dose-dependent inhibition of the cysteinyl-leukotriene component of antigen-induced bronchoconstriction in sensitized guinea-pigs [50]. BWA4C also exhibited ex-vivo $\mathrm{LTB}_{4}$ synthesis when dosed orally to volunteers. Zileuton had similar in vitro potency and selectivity to acetohydroxamates and inhibited leukotriene synthesis ex-vivo [49]. Zileuton inhibited airway microvascular leakage and bronchoconstriction induced by inhaled allergen in the sensitized guinea-pig model [51], in addition to inhibiting leucocyte accumulation [51, 52]. Zileuton produced dose-dependent inhibition of leukotriene synthesis exvivo following oral administration to volunteers, with a duration of action of $6 \mathrm{~h}$ at doses of 600-800 $\mathrm{mg}$ [53].

A new series of non-redox 5-lipoxygenase inhibitors, devoid of iron-chelating properties, the methoxyalkylthiazoles, such as ICI D2138, are most potent and selective inhibitors of 5-lipoxygenase [54]. ICI D2138 exhibits prolonged inhibition of ex-vivo leukotriene synthesis when administered orally to volunteers, with a half-life of around $12 \mathrm{~h}$.

Inhibitors of FLAP such as MK-886 and MK-591 which is a structural analogue of MK-886, have no direct activity on 5-LO but antagonizes FLAP thus preventing the translocation of the enzyme to the membrane [55]. MK886 is a highly selective compound with no effects of prostaglandin synthesis. MK886 inhibits antigen-induced bronchoconstriction in Ascaris-sensitive squirrel monkeys [56, 57]. MK-591 [58] inhibits LTB $_{4}$ synthesis ex-vivo by up to $90 \%$ and urinary $\mathrm{LTE}_{4}$ by $>80 \%$ at $24 \mathrm{~h}$, with a half-life of $6 \mathrm{~h}$ [59]. Although FLAP antagonists REV5091 and WY50295 were shown to be active in vitro and in animals, they were inactive in inhibiting leukotriene synthesis in volunteers [60, 61]. BAY-X-1005 inhibits anti-immunoglobulin E(IgE) challenge in human airways in vitro [62].

\section{Effects in asthma (table 1)}

Inhibition of bronchial challenges. Zileuton has been the most extensively evaluated in human studies in vivo. It inhibits bronchoconstriction induced by cold, dry air and aspirin-induced asthma [63, 64]. In addition, nasal, gastrointestinal and dermal reactions were also inhibited, together with urinary LTE $_{4}$ excretion [64]. Similarly, ZD-2138 was also effective in inhibiting aspirin-induced asthma [65]. The effects of several 5-LO inhibitors on allergen-induced early and late responses have been more variable [66-71]. Whilst zileuton and ZD-2138 did not inhibit early and late asthmatic responses $[66,68]$, the inhibitors, MK-886, MK-0591 and BAY-X-1005, have 
Table 1. - Effect of leukotriene biosynthesis inhibitors in asthma

\begin{tabular}{|c|c|c|c|c|c|}
\hline $\begin{array}{l}\text { Challenge/ } \\
\text { type of asthma }\end{array}$ & $\begin{array}{l}\text { Compound } \\
\text { and dose }\end{array}$ & Effect & $\begin{array}{l}\text { First } \\
\text { author }\end{array}$ & Year & [Ref] \\
\hline Cold, dry air & $\begin{array}{l}\text { Zileuton } \\
800 \mathrm{mg} \text {, oral }\end{array}$ & $\begin{array}{l}\uparrow 47 \% \text { of cold, dry air } \\
\text { needed for } 10 \% \downarrow \text { in FEV } 1\end{array}$ & ISRAEL & 1990 & [63] \\
\hline \multirow[t]{7}{*}{ Allergen } & $\begin{array}{l}\text { Zileuton } \\
800 \mathrm{mg} \text {, oral }\end{array}$ & No effect on EAR and LAR & HuI & 1991 & [66] \\
\hline & $\begin{array}{l}\text { MK- } 886 \\
500 \mathrm{mg} 1 \mathrm{~h} \text { before } \\
\text { and } 250 \mathrm{mg} 2 \mathrm{~h} \text { after, } \\
\text { oral }\end{array}$ & $\begin{array}{l}\downarrow \text { EAR } 58 \% \mathrm{FEV}_{1} * \\
\downarrow \text { LAR } 44 \% \text { FEV } 1 \\
\text { No effect on AHR }\end{array}$ & FRIEDMAN & 1993 & [67] \\
\hline & $\begin{array}{l}\text { ZD-2138 } \\
350 \mathrm{mg} 4 \mathrm{~h} \text { before, } \\
\text { oral }\end{array}$ & $\begin{array}{l}\text { No effect on EAR } \\
\text { and LAR }\end{array}$ & SHuAIB NASSER & 1994 & {$[68]$} \\
\hline & $\begin{array}{l}\text { MK- } 0591 \\
250 \mathrm{mg}, 24,12 \text { and } \\
1.5 \mathrm{~h} \text { before, oral }\end{array}$ & $\begin{array}{l}\downarrow \text { EAR } 79 \% \\
\downarrow \text { LAR } 39 \% \text { (LAR } \\
\text { reappeared } 3 \text { h later) }\end{array}$ & Diamant & 1995 & [69] \\
\hline & & No effect on AHR & DaHLEN & 1993 & {$[70]$} \\
\hline & $\begin{array}{l}\text { BAY-X-1005 } \\
750 \mathrm{mg}, 4 \mathrm{~h} \text { before, oral }\end{array}$ & $\downarrow$ EAR $68 \%$ FEV 1 & O'BYRNE & 1994 & [71] \\
\hline & $\begin{array}{l}500 \mathrm{mg} \text { b.i.d., } 3 \text { days } \\
\text { before and on day }\end{array}$ & $\begin{array}{l}\downarrow \text { EAR } 79 \% \\
\downarrow \text { LAR 53\% }\end{array}$ & & & \\
\hline \multirow[t]{2}{*}{ Aspirin } & $\begin{array}{l}\text { Zileuton } \\
600 \mathrm{mg} \text { q.i.d. for } 7 \text { days, } \\
\text { oral }\end{array}$ & Complete blockade & ISRAEL & 1993 & [64] \\
\hline & $\begin{array}{l}\text { ZD-2138 } \\
350 \mathrm{mg}, 4 \mathrm{~h} \text { before, oral }\end{array}$ & $\downarrow$ fall in FEV1 $20 \%$ & Shuarb Nasser & 1994 & {$[65]$} \\
\hline \multirow[t]{2}{*}{$\begin{array}{l}\text { Clinical asthma } \\
\text { (139 patients) }\end{array}$} & $\begin{array}{l}\text { Zileuton } \\
2.4 \mathrm{gm} \cdot \text { day }^{-1}\end{array}$ & $\begin{array}{l}\uparrow 13.4 \% \mathrm{FEV} 1 \\
\downarrow 24 \% \beta \text {-agonist use }\end{array}$ & ISRAEL & 1993 & {$[72]$} \\
\hline & $1.6 \mathrm{gm} \cdot \mathrm{day}^{-1}$ & $\begin{array}{l}\uparrow 10.9 \% \text { FEV } 1 \\
17 \% \downarrow \beta \text {-agonist use }\end{array}$ & & & \\
\hline
\end{tabular}

\footnotetext{
* Indicates attenuation of the induced fall in FEV1. EAR: early asthmatic response; LAR: late asthmatic response; AHR: airway
} hyperresponsiveness after allergen challenge; FEV1: forced expiratory volume in one second; $\uparrow:$ increase; $\downarrow$ : decrease.

been reported to inhibit both responses [67, 69-71]. MK886 and MK-0591 protected against the late asthmatic response between $3-8 \mathrm{~h}$, but this was subsequently lost $[67,69]$. These compounds had no effect on allergeninduced airway hyperresponsiveness, despite effective blockade of $\mathrm{LTB}_{4}$ biosynthesis and $\mathrm{LTE}_{4}$ excretion at the time of measurement of airway responsiveness. In the study with a single oral dose of $800 \mathrm{mg}$ zileuton [66], there was an almost complete blockade of $\mathrm{LTB}_{4}$ biosynthesis ex-vivo, and a nearly $50 \%$ inhibition of urinary $\mathrm{LTE}_{4}$, whilst in the MK-886 studies, $\mathrm{LTB}_{4}$ biosynthesis $e x$-vivo was reduced by $54 \%$, with an $80 \%$ reduction in $\mathrm{LTE}_{4}$ urinary excretion at 3-9 $\mathrm{h}$ postchallenge. Almost complete blockage of $\mathrm{LTB}_{4}$ biosynthesis and $\mathrm{LTE}_{4}$ urinary excretion were observed with MK-0591. Zileuton also reduced allergen-induced nasal congestion, and selectively blocked leukotriene release in nasal lavage fluid in patients with allergic rhinitis [73].

\section{Clinical asthma}

Despite the relative lack of effect of zileuton on allergen responses, in a 4 week placebo-controlled trial in patients with mild to moderate asthma, it improved airway function and symptoms. At the highest dose of 2.4 $\mathrm{gm} \cdot \mathrm{day}^{-1}$, there were a mean increase in $\mathrm{FEV} 1$ of $13.4 \%$, a decrease in $\beta$-agonist usage by $24 \%$, an improvement in morning peak expiratory flow rate of $10 \%$, a decrease in overall symptom scores of $37 \%$, and a decrease in urinary leukotriene excretion by $39 \%$ [72]. There were no significant side-effects reported. Another long-term study with zileuton examined its protective effect against cold, dry air-induced bronchoconstriction after 13 weeks of pretreatment. The protection observed was found to persist for up to 10 days after discontinuation of zileuton, which has a half-life of only $2.3 \mathrm{~h}$ [74].

\section{Leukotriene receptor antagonists}

There are two classes of receptors for leukotrienes, those for the dihydroxy-leukotrienes, $\mathrm{LTB}_{4}$, termed BLTreceptors, and those for cysteinyl leukotrienes, CysLTreceptors, according to the recent International Union of Pharmacology (IUPHAR) receptor nomenclature. Specific membrane CysLT-receptors have been described, using functional receptor assays on isolated smooth muscle preparations and receptor ligand-binding studies in mammalian lung tissues [75]. Although few synthetic agonists for CysLT-receptors now exist, many antagonists have been produced. Two broad subgroups of Cys 
LT-receptors have been recognized, those blocked by

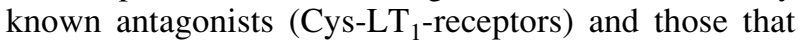
are resistant to blockade (Cys-LT $\mathrm{L}_{2}$-receptors). One recent antagonist appears to have activity both for Cys-LT ${ }_{1}$ receptors and $\mathrm{Cys}-\mathrm{LT}_{2}$-receptors [76]. In human airway smooth muscle, $\mathrm{LTC}_{4}, \mathrm{LTD}_{4}$ and $\mathrm{LTE}_{4}$ all activate a Cys-LT ${ }_{1}$-receptor, although a subclass of Cys- $\mathrm{LT}_{1}$-receptor may be activated specifically by $\mathrm{LTE}_{4}$ alone. In human pulmonary vasculature, a Cys- $\mathrm{LT}_{2}$-receptor has been identified. Cys-LT ${ }_{1}$-receptor is likely to be G-protein-coupled, leading to calcium mobilization on activation [77].

Early compounds in the development of receptor antagonists were relatively weak in activity. The first leukotriene receptor antagonist of the hydroxyacetophenone class described was FPL-55712 [78], which exhibited poor bioavailability and a short half-life. Other compounds within the same class, e.g. LY 171883, L-649,923, and YM-16638, were synthesized, but did not possess sufficient potency to act effectively as an $\mathrm{LTD}_{4}$ receptor antagonist. In addition to having no effect on allergeninduced responses, L-649,923 was poorly-tolerated, with a high incidence of gastrointestinal effects [79].
The newer generation of leukotriene antagonists, such as ICI 204,219 (or Accollate), the quinolones MK-571 and RG-12,525, ONO-1078 (prankulast) and SK\&F 104,353 are more promising. SK\&F 104,353 has little oral activity and has been studied via the inhaled route. These compounds are at least 200 fold more potent than earlier leukotriene antagonists in $\left[{ }^{3} \mathrm{H}\right]-\mathrm{LTD}_{4}$ binding assays [80]. The efficacy and safety of potent leukotriene receptor antagonists against leukotriene-induced bronchoconstriction in normals and asthmatics has been shown in several studies. ICI 204,219, at a single oral dose of 40 $\mathrm{mg}$, shifted the $\mathrm{LTD}_{4}$-induced bronchoconstriction doseresponse curve by 100 -fold and provided significant antagonism for at least $24 \mathrm{~h}$ in normal subjects, with no apparent side-effects [81]. MK-571 provided a shift of greater than 88 fold in asthmatic patients [82]. The introduction of these potent antagonists has been critical in defining the role of $\mathrm{LTD}_{4}$ in bronchial asthma.

Inhibition of bronchial challenges (table 2). A number of studies have now been carried out showing that leukotriene receptor antagonists inhibit several experimental challenges that provoke airway narrowing in patients

Table 2. - Effect of leukotriene receptor antagonists on clinical challenges in asthma

\begin{tabular}{|c|c|c|c|c|c|}
\hline Challenge & Compound & Effect & First author & Year & [Ref] \\
\hline \multirow[t]{4}{*}{ Exercise } & $\begin{array}{l}\text { ICI } 204,219 \\
20 \mathrm{mg} \text {, oral }\end{array}$ & $\downarrow$ by $40 \% \mathrm{FEV}_{1} *$ & FINNERTY & 1992 & [83] \\
\hline & $\begin{array}{l}\text { ICI } 204,219 \\
400 \mu \mathrm{g}, \text { inhaled }\end{array}$ & $\downarrow$ by $49 \%$ FEV 1 & MAKKER & 1993 & {$[84]$} \\
\hline & $\begin{array}{l}\text { SK\&F } 104,353 \\
800 \mu g, \text { inhaled }\end{array}$ & $\downarrow$ by $50 \% \mathrm{FEV}_{1}$ & RoBUSCHI & 1992 & {$[85]$} \\
\hline & $\begin{array}{l}\text { MK-571 } \\
160 \mathrm{mg} \text {, oral }\end{array}$ & $\downarrow$ by $68 \% \mathrm{FEV}_{1}$ & ManNING & 1990 & {$[43]$} \\
\hline \multirow[t]{5}{*}{ Allergen } & $\begin{array}{l}\text { ICI } 204,219 \\
40 \mathrm{mg} \text {, oral }\end{array}$ & $\begin{array}{l}\downarrow \text { EAR } 81 \% \text { FEV1 } \\
\downarrow \text { LAR } 55 \% \text { FEV1 } \\
\downarrow \text { AHR }\end{array}$ & TAYLOR & 1991 & [86] \\
\hline & $\begin{array}{l}\text { ICI } 204,219 \\
1,600 \mu \mathrm{g}, \text { inhaled }\end{array}$ & $\begin{array}{l}\downarrow \text { EAR } \\
\text { No change in LAR }\end{array}$ & O'ShaughNEsSy & 1993 & {$[90]$} \\
\hline & $\begin{array}{l}\text { ICI } 204,219 \\
40 \mathrm{mg} \text {, oral }\end{array}$ & $\begin{array}{l}\uparrow 10 \text { fold of cat } \\
\text { allergen to cause } \\
20 \% \text { fall in FEV } 1\end{array}$ & FindLay & 1992 & {$[87]$} \\
\hline & $\begin{array}{l}\text { MK-571 } \\
450 \mathrm{mg} \text {, infused }\end{array}$ & $\begin{array}{l}\downarrow \text { EAR } 88 \% \text { FEV } 1 \\
\downarrow \text { LAR } 68 \% \text { FEV } 1\end{array}$ & RASMUSSEN & 1994 & {$[88]$} \\
\hline & $\begin{array}{l}\text { ICI } 204,219 \\
20 \mathrm{mg} \text {, oral }\end{array}$ & $\begin{array}{l}\uparrow 5.5 \text { fold in } \\
\text { allergen dose }\end{array}$ & DAHLEN & 1994 & [89] \\
\hline \multirow[t]{2}{*}{ Aspirin } & $\begin{array}{l}\text { SK\&F } 104,353 \\
893 \mu \mathrm{g}, \text { inhaled }\end{array}$ & $\downarrow 43-74 \%$ of $\mathrm{FEV}_{1}$ & Christie & 1991 & [91] \\
\hline & $\begin{array}{l}\text { MK-0679 } \\
750 \mathrm{mg} \text {, oral }\end{array}$ & $\begin{array}{l}\uparrow \text { aspirin dose by } \\
4.4 \text { fold }\end{array}$ & DAHLEN & 1993 & {$[92]$} \\
\hline Dipyrone & $\begin{array}{l}\text { ONO-1078 } \\
225 \mathrm{mg} \text {, oral }\end{array}$ & $\begin{array}{l}\uparrow 14 \text { fold in dipyrone } \\
\text { dose }\end{array}$ & YАMAMOTO & 1994 & {$[93]$} \\
\hline \multirow[t]{2}{*}{$\begin{array}{l}\text { PAF } \\
\text { (normal subjects) }\end{array}$} & $\begin{array}{l}\text { ICI } 204,219 \\
40 \mathrm{mg} \text {, oral }\end{array}$ & $\begin{array}{l}\downarrow 59 \% \text { of fall in } \\
\text { sGaw after PAF }\end{array}$ & KIDNEY & 1993 & [94] \\
\hline & $\begin{array}{l}\text { SK\&F } 104,353 \\
1.2 \mathrm{mg}, \text { inhaled }\end{array}$ & $\begin{array}{l}\downarrow 12.6 \% \text { of fall in } \\
\text { sGaw after PAF }\end{array}$ & SPENCER & 1991 & [95] \\
\hline
\end{tabular}

* Indicates attenuation of the induced fall in FEV1. sGaw: Specific airways conductance; PAF: platelet-activating factor. For further abbreviations see legend to table 1 . 
with asthma, such as exercise, allergen, and aspirin. Exercise-induced asthma is partially inhibited by approximately $50 \%$ in most studies [43, 83-85], despite the likelihood that the degree of leukotriene receptor antagonism achieved in each study could have been different. The studies using allergen challenge are of interest because both the early and late phase responses are inhibited by the leukotriene antagonists, ICI 204,219 (40 mg orally) and MK-571 [86-88]. ICI 204,219 also inhibited airway hyperresponsiveness to histamine at $6 \mathrm{~h}$ after allergen challenge [86]. ICI 204,219 inhibited the airway response to cumulative allergen challenge by 5.5 fold increase in allergen dose, associated with a shorter recovery time [89]. When administered by inhalation, ICI 204,219 (1.6 $\mathrm{mg}$ ) reduced the early but not the late asthmatic response [90]. Inhaled L-648051 administered over 7 days attenuated the early and late responses to inhaled allergen [96]. In normal subjects, PAF-induced bronchoconstriction was inhibited by the $\mathrm{LTD}_{4}$ leukotriene antagonists, ICI 204,219 [94] and SK\&F 104,353 [95], in accordance with the observation that platelet-activating factor (PAF)induces an increase in urinary $\mathrm{LTE}_{4}$ excretion [97].

The profile of activities demonstrated by the leukotriene antagonists is different from that observed with single doses of inhaled or oral corticosteroids, which do not inhibit exercise or the acute response to allergen challenge. Aspirin-induced bronchoconstriction in aspirinsensitive asthmatics was inhibited by the leukotriene receptor antagonists MK-069 and SK\&F 104,353 [91, 92]. These results contrast with those obtained with potent receptor antagonists of PAF, which demonstrate little or no significant activity against allergen- or exercise-induced bronchoconstriction [98-100], and in trials involving moderately severe asthmatic patients [101].

Oral prankulast (ONO-1078), after one week of treatment, causes a small (half of one doubling dilution of methacholine provocative concentration producing a $20 \%$ decrease in forced expiratory volume in one second (PC20)) improvement in bronchial hyperresponsiveness in stable asthmatic patients [102]. Inhaled L-648051 also improved bronchial hyperresponsiveness by 1.5 doubling dilutions of methacholine, after 9 days of treatment [96]. These studies indicate that, as after inhaled steroids, bronchial hyperresponsiveness improves after treatment with leukotriene antagonists. They are also in agreement with studies showing that $\mathrm{LTC}_{4}$ interacts synergistically with histamine and prostaglandin $\mathrm{D}_{2}$ [103], and that $\mathrm{LTE}_{4}$ increases histamine airway responsiveness in asthmatics but not in normal subjects [104, 105]. It is possible that further improvement may occur with longer periods of treatment with leukotriene antagonists.

\section{Studies in clinical asthma (table 3)}

Single dosing. Results from several studies show that leukotriene antagonists, like synthesis inhibitors, produce significant improvement in airways function, together with a reduction in symptoms. In a study of 10 patients with mild-to-moderate asthma, a single oral dose of ICI 204,219 induced significant bronchodilation, with a mean increase of $8 \%$ in FEV1 (range 2-14\%) [106]. However, inhaled ICI 204,219 (1,600 $\mu \mathrm{g}$ dose $)$ did not induce bronchodilatation [107], whilst SK\&F 104,353 by inhalation was effective (5\% mean increase in FEV1) [108]. In 12 moderately severe asthmatics, infusion of MK571 resulted in a mean $20 \%$ increase in FEV 1 noticed 20 min after the start of infusion, and persisting for the $5 \mathrm{~h}$ observation period $[109,115]$. The bronchodilator properties of LT antagonists and of the $\beta_{2}$-adrenergic agonist, salbutamol, appear to be additive. In addition, the degree of baseline airway obstruction was correlated with the degree of bronchodilation achieved with MK-571. Similarly, in eight patients with aspirin-sensitive asthma, MK-679, the (R)-enantiomer of MK-571, by oral administration, induced a $5-34 \%$ (mean $18 \%$ ) improvement in FEV1, lasting for at least $9 \mathrm{~h}$ [110]. These studies suggest that persistent activation of leukotriene receptors to increase airway tone is present in patients with chronic asthma. The bronchodilator response correlated strongly with the severity of asthma and with aspirin sensitivity. It is interesting to note that leukotriene receptor antagonists do not induce bronchodilatation in normal volunteers [81, 82].

Multiple dosing. The earlier relatively weak leukotriene receptor antagonist LY 171,883 (600 mg b.i.d. for 6 weeks) caused a small improvement in basal lung function, with some reduction in the use of $\beta_{2}$-andrenergic agonist relief medication [111]. It is possible that this beneficial effect may have resulted from its other properties, such as phosphodiesterase inhibition. Studies using more potent and specific antagonists have recently been completed. MK-571 administered orally for 6 weeks resulted in a mean increase in FEV1 of 8-14\%, a decrease in daytime symptom scores by $30 \%$, a decrease in $\beta$ agonist inhaler use by $30 \%$ and improved diurnal variation in peak expiratory flow rate [112]. Development of MK-571 has been suspended, in favour of the (R)enantiomer, MK-679. However, this has also been abandoned because of hepatotoxicity, which is unrelated to its leukotriene receptor antagonism.

In a 6 week study of ICI $204,209(5,10$ or $20 \mathrm{mg}$ b.i.d.) in patients with mild to moderate asthma, a dosedependent improvement in symptoms was observed. The $40 \mathrm{mg} \cdot \mathrm{kg}^{-1}$ dosage led to a significant improvement of evening peak expiratory flow, rescue $\beta$-agonist inhaler use (reduced by $30 \%$ ), nocturnal awakenings (reduced by $46 \%$ ), morning asthma symptoms and daytime symptoms (reduced by 26\%) [113]. ICI 204,219 was more effective in subjects who had the lowest predicted FEV1 at entry to the study, and a linear response was observed with increasing doses of the antagonist [113].

In general, leukotriene receptor antagonists and inhibitors were well-tolerated in studies where the treatment period was over one week. Only mild adverse events have been reported, such as headaches and gastrointestinal disturbances. Some patients on zileuton have reported dyspepsia [72], and LY-171,883 was associated with mild diarrhoea in some patients [111]. However, in many studies, the incidence of reported adverse effects was similar to that reported in the placebo group [72, 111, 113]. 
Table 3. - Effect of leukotriene receptor antagonists in clinical asthma

\begin{tabular}{|c|c|c|c|c|c|}
\hline Compound & $\begin{array}{l}\text { Type of } \\
\text { asthma }\end{array}$ & Effects & First author & Year & [Ref] \\
\hline \multicolumn{6}{|l|}{ Single dosing } \\
\hline $\begin{array}{l}\text { ICI } 204,219 \\
40 \mathrm{mg}, \text { oral }\end{array}$ & $\begin{array}{l}\text { Mild-moderate } \\
(\mathrm{n}=10)\end{array}$ & $\begin{array}{l}\uparrow 8 \% \mathrm{FEV}_{1} * \\
(2-14 \%)\end{array}$ & HuI & 1991 & {$[106]$} \\
\hline $\begin{array}{l}\text { ICI } 204,219 \\
1,600 \mu \mathrm{g}, \text { inhaled }\end{array}$ & $\begin{array}{l}\text { Moderate } \\
(n=10)\end{array}$ & Nil & KIPS & 1993 & {$[107]$} \\
\hline $\begin{array}{l}\text { SK\&F } 104,353 \\
800 \mu \mathrm{g}, \text { inhaled }\end{array}$ & $(n=10)$ & $\uparrow 5 \% \mathrm{FEV}_{1}$ & Joos & 1991 & {$[108\}$} \\
\hline $\begin{array}{l}\text { MK-571 } \\
776 \mathrm{mg} \text { over } 6 \mathrm{~h}, \text { infused }\end{array}$ & $\begin{array}{l}\text { Moderately severe } \\
(n=12)\end{array}$ & $\uparrow 22 \% \mathrm{FEV}_{1}$ & $\mathrm{G}_{A D D Y}$ & 1992 & [109] \\
\hline $\begin{array}{l}\text { MK-0679 } \\
825 \mathrm{mg} \text {, oral }\end{array}$ & $\begin{array}{l}\text { Aspirin-sensitive } \\
(\mathrm{n}=8)\end{array}$ & $\begin{array}{l}\uparrow 18 \% \mathrm{FEV}_{1} \\
(5-34 \%)\end{array}$ & DAHLÉn & 1993 & [110] \\
\hline \multicolumn{6}{|l|}{ Multiple dosing } \\
\hline $\begin{array}{l}\text { ICI } 204,219 \\
5,10 \text { or } 20 \mathrm{mg} \\
\text { b.i.d. for } 6 \text { weeks }\end{array}$ & $\begin{array}{l}\text { Mild-moderate } \\
(\mathrm{n}=276)\end{array}$ & $\begin{array}{l}\text { At } 40 \text { mg } \cdot \text { day }^{-1} \\
\downarrow \text { rescue } \beta \text {-agonist } \\
\text { (30\%) } \\
\downarrow \text { nocturnal awakening } \\
\text { (46\%) } \\
\downarrow \text { day symptom }(26 \%) \\
\uparrow \text { FEV } 1(11 \%)\end{array}$ & SPECTOR & 1994 & [113] \\
\hline $\begin{array}{l}\text { MK-571 } \\
75 \mathrm{mg} \text { t.i.d., } 2 \text { weeks, } \\
\text { then } 50 \mathrm{mg} \text { t.i.d. for } \\
4 \text { weeks }\end{array}$ & $(n=43)$ & $\begin{array}{l}\uparrow 8-14 \% \text { FEV } 1 \\
\downarrow 30 \% \text { symptom scores }\end{array}$ & MARGOLSKEE & 1991 & [112] \\
\hline $\begin{array}{l}\text { LY- } 171,883 \\
600 \text { mg b.i.d., } \\
6 \text { weeks }\end{array}$ & $\begin{array}{l}\text { Mild-moderate } \\
(\mathrm{n}=138)\end{array}$ & $\begin{array}{l}\uparrow \text { Mean weekly FEVI } \\
\text { of } 4.5 \% \\
\downarrow \text { use of } \beta \text {-agonist }\end{array}$ & CLOUd & 1989 & [111] \\
\hline $\begin{array}{l}\text { RG } 12525 \\
50 \mathrm{mg} \text { q.i.d. } 10 \text { days }\end{array}$ & $(n=29)$ & $\uparrow 7.9 \% \mathrm{FEV} 1$ & WAHEDNA & 1992 & [114] \\
\hline
\end{tabular}

* Indicates change in FEV1 from baseline.

\section{Inhibition of leukotriene: effects in asthma therapy}

Although it is likely that many mediators are involved in the pathogenesis of the asthmatic diathesis, inhibition of the effects of leukotrienes by receptor antagonism or inhibition of synthesis leads to improvement in symptoms and bronchodilation in patients with asthma. Although leukotriene receptor antagonists appear to be more effective than the synthesis inhibitors in blocking the late asthmatic response, the limited clinical trials that have been published show that both classes have similar effects in clinical improvement. It is too early to say whether there will be an advantage of one class over the other, despite the theoretical advantage of leukotriene 5-LO inhibitors in blocking leukotriene $\mathrm{B}_{4}$ synthesis.

Further clinical studies of inhibitors of leukotriene effects should clarify their exact place in asthma therapy, but it is important to consider the mechanism of action of these drugs in asthma. Some of the improvement may be secondary to inhibition of airway microvascular leakage and oedema. Their mechanism of bronchodilator effect in asthma would be similar to that provided by anti-inflammatory agents, such as corticosteroids, in that these effects are "indirect". Whether leukotriene receptor antagonists or inhibitors improve bronchial responsiveness to bronchoconstrictor stimuli, such as histamine or methacholine, on a longer term basis as do topical corticosteroids needs investigation, as do their potential effects on the cellular influx of inflammatory cells, in particular, eosinophils in the airway. They may also prevent the long-term consequences of asthma, such as worsening decline in lung function, as supported by results in a rat model [116].

Current guidelines for the therapy of asthma emphasize the central role of inhaled corticosteroid therapy with the use of bronchodilators, mainly short-acting $\beta$ adrenergic agonists on an as-needed basis [2]. Inhibitors of leukotriene effects may be considered at all stages of asthma therapy. Firstly, they could be introduced at Step 1 of the guidelines as regular therapy in patients with symptoms or $\beta$-agonist usage of more than 3-4 times per week. Secondly, they could be introduced, together with inhaled steroid therapy, for a potential synergistic or additive effect, to limit or reduce the dose of inhaled steroid therapy. In this respect, it would be important to determine any steroid-sparing properties of these compounds. Leukotriene receptor antagonists or synthesis inhibitors appear to provide useful bronchodilation over and above what $\beta_{2}$-adrenergic agonists may provide. Most of these drugs are active by the oral route, and this may possess the advantage of improved patient compliance with once or twice daily oral dosing over 
inhaled therapy. With a relatively safe profile of unwanted side-effects so far, compliance may be better than with the use of regular twice daily inhaled steroid therapy [117].

The introduction of leukotriene antagonists and synthesis inhibitors in the therapy of asthma will represent an important breakthrough in asthma therapy. These drugs represent the first class of mediator antagonists that have provided clinical benefit in asthma, in contrast to the disappointing results seen with very potent histamine antagonists. Although further work needs to be done, one should be optimistic as to their future contribution in the management of asthma; they are likely to become an established class of anti-asthma drugs.

Acknowledgements: The author thanks C. Calder of Franklin Scientific Projects, London, for her help in providing many of the references listed, and $\mathrm{M}$. Beringer for invaluable secretarial assistance.

\section{References}

1. Barnes PJ. New concepts in the pathogenesis of bronchial hyperresponsiveness and asthma. J Allergy Immunol 1989; 83: 1013-1025.

2. British Thoracic Society. Guidelines for the management of asthma: a summary. Br Med $J$ 1993; 306: 776-782.

3. Djukanovic R, Roche WR, Wilson JW, et al. Mucosal inflammation in asthma. Am Rev Respir Dis 1990; 142: 434-457.

4. Hamid Q, Azzawi M, Ying S, et al. Expression of mRNA for interleukins in mucosal bronchial biopsies from asthma. J Clin Invest 1991; 87: 1541-1546.

5. Broide DH, Firestein GS. Endobronchial allergen challenge: demonstration of cellular source of granulocyte macrophage colony-stimulating factor by in situ hybridization. J Clin Invest 1991; 88: 1048-1053.

6. Broide DH, Lotz M, Cuomo AJ, Coburn DA, Federman EC, Wasserman SI. Cytokines in symptomatic asthmatic airways. J Allergy Clin Immunol 1992; 89: 958-967.

7. Weller PF, Lee CW, Foster DW, Corey ET, Austen KF, Lewis RA. Generation and metabolism of 5-lipoxygenase pathway leukotrienes by human eosinophils: predominant production of leukotriene $\mathrm{C}_{4}$. Proc Natl Acad Sci USA 1983; 80: 7626-7630.

8. Chung KF, Barnes PJ. Role of inflammatory mediators in asthma. Br Med Bull 1992; 48: 135-148.

9. Rouzer CA, Matsumoto T, Samuelsson B. Single protein from human leukocytes possesses 5-lipoxygenase and leukotriene A synthase activities. Proc Natl Acad Sci USA 1986; 83: 857-861

10. Rouzer CA, Samuelsson B. On the nature of the 5- lipoxygenase reaction in human leukocytes: enzyme purification and requirement for multiple stimulatory factors. Proc Natl Acad Sci USA 1985; 82: 6040-6044.

11. Miller DK, Gillard JW, Vickers PJ, et al. Identification and isolation of a membrane protein necessary for leukotriene production. Nature 1990; 343: 278-281.

12. Haeggstrom JZ, Wetterholm A, Vallee BL, Samuelsson B. Leukotriene $\mathrm{A}_{4}$ hydrolase: an epoxide hydrolase with peptidase activity. Biochem Biophys Res Commun 1990; 173: 431-437.

13. Lam BK, Penrose JF, Freeman GJ, Austen KF. Expression cloning of a cDNA for human leukotriene $\mathrm{C}_{4}$ synthase, an integral membrane protein conjugating reduced glutathione to leukotriene $\mathrm{A}_{4}$. Proc Nat Acad Sci USA 1994; 91: 7663-7667.

14. Sala A, Voelkel N, Maclouf J, Murphy RC. Leukotriene $\mathrm{E}_{4}$ elimination and metabolism in normal human subjects. J Biol Chem 1990; 265: 21771-21778.

15. Maltby NH, Taylor GW, Ritter JM, Moore K, Fuller RW, Dollery CT. Leukotriene $\mathrm{C}_{4}$ elimination and metabolism in man. J Allergy Clin Immunol 1990; 85: 3-9.

16. Feinmark SJ, Cannon PJ. Endothelial cell leukotriene $\mathrm{C}_{4}$ synthesis results from intercellular transfer of leukotriene $\mathrm{A}_{4}$ synthesized by polymorphonuclear leukocytes. $J$ Biol Chem 1986; 261: 16466-16472.

17. Bigby TD, Lee DM, Meslier N, Gruenert DC. Leukotriene $\mathrm{A}_{4}$ hydrolase activity of human airway epithelial cells. Biochem Biophys Res Commun 1989; 164: 1-7.

18. Silberstein DS, Owen WF, Gasson JC, et al. Enhancement of human eosinophil cytotoxicity and leukotriene synthesis by biosynthetic (recombinant) granulocytemacrophage colony-stimulating factor. J Immunol 1986; 137: 3290-3294.

19. Takafuji S, Bischoff SC, De Weck AL, Dahinden CA. IL-3 and IL-5 prime normal human eosinophils to produce leukotriene $\mathrm{C}_{4}$ in response to soluble agonists. $J$ Immunol 1991; 147: 3855-3861.

20. Dahlén S-E, Hedqvist P, Hammarström S, Samuelsson B. Leukotrienes are potent constrictors of human bronchi. Nature 1980; 288: 484-486.

21. Piper PJ, Samhoun MN. Comparison of the actions of leukotriene $\mathrm{E}_{4}$ with those of leukotrienes $\mathrm{B}_{4}, \mathrm{C}_{4}$ and $\mathrm{D}_{4}$ on guinea-pig lung and ileal smooth muscle in vitro. In: Samuelsson B, Paoletti R, Ramwell P, eds. Advances in Prostaglandin, Thromboxane and Leukotriene Research. Vol. 12. New York, Raven Press, 1983; pp. 127-131.

22. Barnes NC, Piper PJ, Costello JF. Comparative effects of inhaled leukotriene $\mathrm{C}_{4}$, leukotriene $\mathrm{D}_{4}$, and histamine in normal human subjects. Thorax 1984; 39: 500-504.

23. Smith LJ, Greenberger PA, Patterson R, Krell RD, Bernstein PR. The effect of inhaled leukotriene $D_{4}$ in humans. Am Rev Respir Dis 1985; 131: 368-372.

24. Weiss JW, Drazen JM, McFadden ERJ, et al. Airway constriction in normal humans produced by inhalation of leukotriene D: potency, time course, and effect of aspirin therapy. J Am Med Assoc 1983, 249: 2814-2817.

25. Davidson $\mathrm{AB}$, Lee $\mathrm{TH}$, Scanlon PD, et al. Bronchoconstrictor effects of leukotriene $\mathrm{E}_{4}$ in normal and asthmatic subjects. Am Rev Respir Dis 1987; 135: 500-504.

26. Marom Z, Shelhamer JH, Bach MK, Morton DR, Kaliner M. Slow-reacting substances, leukotrienes $C_{4}$ and $D_{4}$, increase the release of mucus from human airways in vitro. Am Rev Respir Dis 1982; 126: 449-451.

27. Coles SJ, Neill KH, Reid LM, Austen KF, Corey EJ, Lewis RA. Effects of leukotrienes $\mathrm{C}_{4}$ and $\mathrm{D}_{4}$ on glycoprotein and lysozyme secretion by human bronchial mucosa. Prostaglandins 1982; 25: 155-170.

28. Johnson HG, McNee ML. Secretagogue responses of leukotriene $\mathrm{C}_{4}, \mathrm{D}_{4}$ : comparison of potency in canine trachea in vivo. Prostaglandins 1983; 25: 237-243.

29. Leikauf GD, Ueki IF, Widdicombe JH, Nadel JA. Alteration of chloride secretion across canine tracheal epithelium by lipoxygenase products of ovaclindonic acid. $J$ Appl Physiol 1986; 250: F47-F53.

30. Woodward DF, Wasserman MA, Weichmann BM. lnvestigation of leukotriene involvement in the vasopermeability response associated with guinea-pig tracheal anaphylaxis: comparison with cutaneous anaphylaxis. Eur J Pharmacol 1983; 93: 9-19. 
31. Hua XY, Dahlen SE, Lundberg JM, Hammerstrom S, Hedqvist $P$. Leukotrienes $\mathrm{C}_{4}$ and $\mathrm{E}_{4}$ cause widespread and extensive plasma extravasation in the guinea-pig. Naunyn Sch Arch Pharmacol 1985; 330: 136-141.

32. Bisgaard H, Kristensen J, Sondergaard J. The effect of leukotriene $\mathrm{C}_{4}$ and $\mathrm{D}_{4}$ on cutaneous blood flow in humans. Prostaglandins 1982; 23: 797-801.

33. Camp RDR, Coutts AA, Greaves MW, Kay AB, Walport MJ. Response of human skin to intradermal injection of leukotrienes $\mathrm{C}_{4}, \mathrm{D}_{4}$ and $\mathrm{B}_{4}$. Br J Pharmacol 1983; 80: 497-502.

34. Bel EH, Van der Veen H, Kramps JA, Dijkman JH, Sterk PJ. Maximal airway narrowing to inhaled leukotriene $\mathrm{D}_{4}$ in normal subjects: comparison and interaction with methacholine. Am Rev Respir Dis 1987; 136: 979-984.

35. Laitinen LA, Laitinen A, Haahtela T, Vilkka V, Spur BW, Lee TH. Leukotriene $\mathrm{E}_{4}$ and granulocytic infiltration into asthmatic airways. Lancet 1993; 341: 989-990.

36. Kumlin M, Dahlen B, Björck T, Zetterstrom O, Granstrom E, Dahlén S-E. Urinary excretion of leukotriene $\mathrm{E}_{4}$ and 11-dehydro-thromboxane $B_{2}$ in response to bronchial provocations with allergen, aspirin, leukotriene $\mathrm{D}_{4}$ and histamine in asthmatics. Am Rev Respir Dis 1992; 146: 96-103.

37. Drazen JM, O'Brien J, Sparrow D, et al. Recovery of leukotriene $\mathrm{E}_{4}$ from the urine of patients with airways obstruction. Am Rev Respir Dis 1992; 146: 104-108.

38. Taylor GW, Taylor I, Black P, et al. Urinary leukotriene $\mathrm{E}_{4}$ after antigen challenge and in acute asthma and allergic rhinitis. Lancet 1989; i: 584-588.

39. Smith CM, Christie PE, Hawksworth RJ, Thien F, Lee $\mathrm{TH}$. Urinary leukotriene $\mathrm{E}_{4}$ levels following allergen and exercise challenge in bronchial asthma. Am Rev Respir Dis 1991; 144: 1411-1413.

40. Smith CM, Hawksworth RJ, Thien FCK, Christie PE, Lee $\mathrm{TH}$. Urinary leukotriene $\mathrm{E}_{4}$ in bronchial asthma. Eur Respir J 1992; 5: 693-699.

41. Christie PE, Tagari P, Ford-Hutchinson AW, et al. Urinary leukotriene $\mathrm{E}_{4}$ concentrations increase after aspirin challenge in aspirin-sensitive asthmatic subjects. Am Rev Respir Dis 1992; 145: 65-69.

42. Taylor IK, Wellings R, Taylor GW, Fuller RW. Urinary leukotriene $\mathrm{E}_{4}$ excretion in exercise induced asthma. $J$ Appl Physiol 1992; 73: 743-748.

43. Manning PJ, Watson RM, Margolskee DJ, Williams VC, Schwartz JJ. Inhibition of exercise-induced bronchoconstriction by MK-571, a potent leukotriene $\mathrm{D}_{4}$ receptor agonist. $N$ Engl J Med 1990; 323: 1736-1739.

44. Lam S, Chan H, Leriche JC, Chan Yeung M, Salari H. Release of leukotrienes in patients with bronchial asthma. J Allergy Clin Immunol 1988; 81: 711-717.

45. Wardlaw AJ, Hay H. Cromwell O, Collins JV, Kay AB. Leukotrienes, $\mathrm{LTC}_{4}$ and $\mathrm{LTB}_{4}$, in bronchoalveolar lavage in bronchial asthma and other respiratory diseases. $J$ Allergy Clin Immunol 1989; 84: 19-26.

46. Crea AEG, Nakhosteen JA, Lee TH. Mediator concentrations in bronchoalveolar lavage fluid of patients with mild asymptotic bronchial asthma. Eur Respir J 1992; 5: 190-195.

47. Wenzel SE. Larsen GL, Johnston G, Voelkel NF, Westcott JY. Elevated levels of leukotriene $\mathrm{C}_{4}$ in bronchoalveolar lavage fluid from atopic asthmatics after endobronchial allergen challenge. Am Rev Respir Dis 1990; 142: 112-119.

48. Ford-Hutchinson AW. Activation of the 5-lipoxygenase pathway of arachidonic acid metabolism. In: Chung KF, Barnes PJ, eds. Pharmacology of the Respiratory Tract:
Experimental and clinical Research. New York, USA. Marcel Dekker, 1993; pp. 375-414.

49. McMillan RM, Girodeau JM, Foster SJ. Selective chiral inhibitors of 5-lipoxygenase with anti-inflammatory activity. Br J Pharmacol 1990; 101: 501-503.

50. Foster SJ, Bruneau P, Walker ER, McMillan RM. Two substituted indazolinones: orally active and selective 5lipoxygenase inhibitors with anti-inflammatory activity. Br J Pharmacol 1990; 99: 113-118.

51. Hui KP, Lotvall J, Chung KF, Barnes PJ. Attenuation of inhaled allergen-induced airway microvascular leakage and airflow obstruction in guinea-pigs by a 5-lipoxygenase inhibitor (A-63162). Am Rev Respir Dis 1991; 143: 1015-1019.

52. Carter GW, Young PR, Albert DH, et al. 5-lipoxygenase inhibitory activity of zileuton. $J$ Pharmacol Exp Ther 1991; 256: 929-937.

53. Rubin P, Dube L, Braeckman R, et al. Pharmacokinetics, safety, and ability to diminish leukotriene synthesis by zileuton, an inhibitor of 5-lipoxygenase. In: Acherman NR, Bonney RJ, Doherty N, eds. Prog Inflam Res Ther 1991; 103-112.

54. McMillan RM, Spruce KE, Crawley GC, Walker ER, Foster SJ. Preclinical pharmacology of ICI D2138, a potent orally-active non-redox inhibitor of 5-lipoxygenase. Br J Pharmacol 1992; 107: 1042-1047.

55. Brideau $\mathrm{C}$, Chan $\mathrm{C}$, Charleson $\mathrm{S}$, et al. Pharmacology of MK-0591 (3-[1-(4-chlorobenzyl)-3-(t-butyl thio)-5-(quinolin-2-yl-methoxy)-indol-2-yl]-2,2-dimethylpropanoic acid), a potent, orally active leukotriene biosynthesis inhibitor. Can J Physiol Pharmacol 1992; 70: 799-807.

56. Depre M, Friedman B, Tanaka W, Van Hecken A, Buntinx A, DeSchepper PJ. Biochemical activity, pharmacokinetics, and tolerability of MK-886, a leukotriene biosynthesis inhibitor, in humans. Clin Pharmacol Ther 1993; 53: 602-607.

57. Gillard J. Ford-Hutchinson AW, Chan C. et al. L-663, 536 (MK-886) (3-[1-(4chlorobenzyl)-3-t-butyl-thio-5-isopropylindol-2-yl]-2,2-dimethylpropanoic acid), a novel, orally active leukotriene biosynthesis inhibitor. Can J Physiol Pharmacol 1989; 67: 456-464.

58. Prasit $\mathrm{P}$, Belley $\mathrm{M}$, Blouin $\mathrm{M}$, et al. A new class of leukotriene biosynthesis inhibitor: the development of MK-0591. J Lipid Mediators 1993; 6: 239-244.

59. Depre M, Friedman B, Van Hecken A. et al. Pharmacokinetics and pharmacodynamics of multiple oral doses of MK0591, a 5-lipoxygenase-activating protein inhibitor. Clin Pharmacol Ther 1994; 56: 22-30.

60. Grimes D, Sturm RJ, Marinari LR, et al. WY-50,295 tromethamine, a novel, orally active 5-lipoxygenase inhibitor: biochemical characterization and antiallergic activity. Eur J Pharmacol 1993; 236: 217-228.

61. Evans JF, Leville C, Mancini JA, et al. 5-lipoxygenase-activating protein is the target of a quinoline class of leukotriene synthesis inhibitors. Mol Pharmacol 1991; 40: 22-27.

62. Gorenne I, Labat C, Gascard JP, et al. (R)-2-[4-(quinolin-2-yl-methoxy)phenyl]-2cyclopentyl] acetic acid (BAY$\mathrm{X}-1005)$, a potent leukotriene synthesis inhibitor: effects on anti-IgE challenge in human airways. $J$ Pharmacol Exp Ther 1994; 268: 868-872.

63. Israel E, Dermarkarian R, Rosenberg M, et al. The effects of a 5-lipoxygenase inhibitor on asthma induced by cold, dry air. $N$ Engl J Med 1990; 323:1740-1744.

64. Israel E, Fischer AR, Rosenberg MA, et al. The pivotal role of 5-lipoxygenase products in the reaction of aspirin-sensitive asthmatics to aspirin. Am Rev Respir 
Dis 1993; 148: 1447-1451.

65. Shuaib Nasser SM, Bell GS, et al. Effects of the 5lipoxygenase inhibiter ZD2138 on aspirin-induced asthma. Thorax 1994; 49: 749-756.

66. Hui KP, Taylor IK, Taylor GW, Rubin P, Kesterson J, Barnes NC. Effect of a 5-lipoxygenase inhibitor on leukotriene generation and airway responses after allergen challenge in asthmatic patients. Thorax 1991; 46: 184-189.

67. Friedman BS, Bel EH, Buntinx A, et al. Oral leukotriene inhibitor (MK-886) blocks allergen-induced airway responses. Am Rev Respir Dis 1993; 147: 839-844.

68. Shuaib Nasser SM, Bell GS, Hawksworth RJ, et al. Effect of the 5-lipoxygenase inhibiter ZD2138 on allergeninduced early and late asthmatic responses. Thorax 1994; 49: 743-748.

69. Diamant Z, Timmers MC, Van der Veen H. The effect of MK-0591, a novel 5-lipoxygenase activating protein (FLAP) inhibitor, on leukotriene biosynthesis and allergen-induced airway responses in asthmatic subjects in vivo. J Allergy Clin Immunol 1995; 95: 42-51.

70. Dahlen SE, Dahlen B, lhre E, et al. The leukotriene biosynthesis inhibiter BAY-X-1005 is a potent inhibitor of allergen-induced airway obstruction and leukotriene formation in man. Am Rev Respir Dis 1993; 147: A837.

71. O'Byrne PM, Watson RM, Strong HA, Wyile G. The effect of treatment with a 5-lipoxygenase inhibitor, BAY$\mathrm{X}-1005$, on allergen-induced asthmatic responses in human subjects. Am J Respir Crit Care Med 1994; 149: A532.

72. Israel E, Rubin P, Kemp JP, et al. The effect of inhibition of 5-lipoxygenase by zileuton in mild-to-moderate asthma. Ann Intern Med 1993; 119: 1059-1066.

73. Knapp HR. Reduced allergen-induced nasal congestion and leukotriene synthesis with an orally active 5-lipoygenase inhibitor. N Engl J Med 1990; 323: 17451748 .

74. Fischer AR, McFadden CA, Frantz R, Cohn J, Drazen JM, Israel E. Chronic inhibition of 5-lipoxygenase decreases airway reactivity to cold, dry air dependent on the acute inhibition of 5-lipoxygenase. Am J Respir Crit Care Med 1994; 149: A1056.

75. Synder DW, Fleisch JH. Leukotriene receptor antagonists as potential therapeutic agents. Ann Rev Pharmacol Toxicol 1989: 29: 123-143.

76. Gardiner PJ, Norman P, Cuthbert NJ, Tudhope SR, Abram TS. Characterisation of the peptidoleukotriene receptor PL2 on the ferret spleen strip. Eur J Pharmacol 1993; 238: 19-26.

77. Crooke ST, Mattern M, Sarau HM, et al. The signal transduction system of the leukotriene $\mathrm{D}_{4}$ receptor. Trends Pharmacol Sci 1989; 10: 103-107.

78. Augstein J, Farmer JB, Lee TB, Sheard P, Tattersall ML. Selective inhibitor of slow reacting substance of anaphylaxis. Nature (New Biol) 1973; 245: 215-217.

79. Britton JR, Hanley SP, Tattersfield AE. The effect of an oral leukotriene $\mathrm{D}_{4}$ antagonist L-649,923 on the response to inhaled antigen in asthma. J Allergy Clin Immunol 1987; 79: 811-816.

80. Cheng JB. Early efficacy data with a newer generation of $\mathrm{LTD}_{4}$ antagonists in antiasthma trials: early promise for a single mediator antagonist. Pulm Pharmacol 1992; 5(2): 77-80.

81. Smith LJ, Geller S, Ebright L, Glass M, Thyrum PT. Inhibition of leukotriene $\mathrm{D}_{4}$-induced bronchoconstriction in normal subjects by the oral $\mathrm{LTD}_{4}$ receptor antagonist ICI 204,219. Am Rev Respir Dis 1990; 141: 988-992.

82. Kips JC. Joos GF, Delepeleire I, et al. MK-571: a potent antagonist of $\mathrm{LTD}_{4}$-induced bronchoconstriction in the human. Am Rev Respir Dis 1991; 144: 617-621.

83. Finnerty JP, Wood-Baker R, Thomson H, Holgate ST. Role of leukotrienes in exercise-induced asthma. Am Rev Respir Dis 1992; 145: 746-749.

84. Makker HK, Lau LC, Thomson HW, Binks SM, Holgate ST. The protective effect of inhaled leukotriene $\mathrm{D}_{4}$ receptor antagonist ICI 204,219 against exercise-induced asthma. Am Rev Respir Dis 1993; 147: 1413-1418.

85. Robuschi M, Riva E, Fuccella LM, et al. Prevention of exercise-induced bronchoconstriction by a new leukotriene antagonist (SK\&F) 104,353. Am Rev Respir Dis 1992; 145: $1285-1288$.

86. Taylor IK, O’Shaughnessy KM, Fuller RM, Dollery CT. Effect of cysteinyl-leukotriene receptor antagonist ICI 204,219 on allergen-induced bronchoconstriction and airway hyperreactivity in atopic subjects. Lancet 1991; 337: 691-694.

87. Findlay SR, Barden JM, Easley CB, Glass M. Effect of the oral leukotriene antagonist ICI 204,219 on the antigen-induced bronchoconstriction in subjects with asthma, J Allergy Clin Immunol 1992; 89: 1040-1045.

88. Rasmussen JB, Eriksson LO, Margolskee DJ, Tagari P, Williams VC, Andersson KE. Leukotriene $\mathrm{D}_{4}$ receptor blockade inhibits the immediate and late bronchoconstrictor responses to inhaled antigen in patients with asthma. J Allergy Clin Immunol 1992; 90: 193-201.

89. Dahlén B, Zetterström O, Björck T, Dahlén S-E. The leukotriene-antagonist ICI 204,219 inhibits the early airway reaction to cumulative bronchial challenge with allergen in atopic asthmatics. Eur Respir J 1994; 7(2): 324-331.

90. O'Shaughnessy KM, Taylor IK, O'Connor B, O'Connell F, Thomson H, Dollery, CT. Potent leukotriene $\mathrm{D}_{4}$ receptor antagonist ICI 204,219 given by the inhaled route inhibits the early but not the late phase of allergen-induced bronchoconstriction. Am Rev Respir Dis 1993; 147: 1431-1435.

91. Christie PE, Smith CM, Lee TH. The potent and selective sulfidopeptide leukotriene antagonist, SK\&F 104, 353, inhibits aspirin-induced asthma. Am Rev Respir Dis 1991; 144: 957-958.

92. Dahlén B, Kumlin M, Margolskee DJ, et al. The leukotriene-receptor antagonist MK-0679 blocks the airway obstruction induced by inhaled lysine-aspirin in aspirin-sensitive asthmatics. Eur Respir J 1993; 6: 1018-1026.

93. Yamamoto H, Nagata M, Kuramitsu K, et al. Inhibition of analgesic-induced asthma by leukotriene receptor antagonist ONO-1078. Am J Respir Crit Care Med 1994; 150: 254-257.

94. Kidney J, Ridge S, Chung KF, Barnes PJ. Inhibition of PAF-induced bronchoconstriction by the oral leukotriene $\mathrm{D}_{4}$ receptor antagonist, ICI 204,219. Am Rev Respir Dis 1993; 147: 215-217.

95. Spencer DA, Evans JM, Green SE, Piper PJ, Costello JF. Participation of the cysteinyl leukotrienes in the acute bronchoconstrictor response to inhaled platelet-activating factor in man. Thorax 1991; 46: 441-415.

96. Bel EH, Timmers MC, Dijkman JH, Stahl EC, Sterk PJ. The effect of an inhaled leukotriene antagonist, L-648,051, on early and late asthmatic reactions and subsequent increase in airway responsivenss in man. J Allergy Clin Immunol 1990; 85: 1067-1075.

97. O'Connor BJ, Uden S, Carty TJ, Eskra JD, Barnes PJ, Chung KF. Inhibitory effects of UK 74505, a potent and specific oral platelet-activating factor (PAF) receptor 
antagonist, on airway and systemic responses to inhaled PAF in man. Am J Respir Crit Care Med 1994; 150: 35-40.

98. Kuitert LM, Hui KP, Uthayarkumar S, et al. Effect of a platelet-activating factor (PAF) antagonist UK-74,505 on allergen-induced early and late response. Am Rev Respir Dis 1993; 147: 82-86.

99. Freitag A, Watson RM, Matsos G, Eastwood C, O’Byrne $\mathrm{PM}$. The effect of an oral platelet-activating factor antagonist, WEB 2086, on allergen-induced asthmatic responses. Thorax 1993; 48: 594-598.

100. Bel EH, De Smet M, Rossing TH, Timmers MC, Dijkman JH, Sterk PJ. The effect of a specific oral PAF-antagonist, MK-287, on antigen-induced early and late asthmatic reactions in man. Am Rev Respir Dis 1991; 143: A811 (Abstract).

101. Kuitert LM, Angus RM, Barnes NC, et al. Effect of a novel potent PAF antagonist, Modipafant, in clinical asthma. Am J Respir Crit Care Med 1995; 151: 1331-1336.

102. Fujimura M, Sakamoto S, Kamio Y, Matsuda T. Effect of a leukotriene antagonist, ONO-1078, on bronchial hyperresponsiveness in patients with asthma. Respir Med 1993; 87: 133-138.

103 Phillips DC, Holgate ST. Interaction of inhaled $\mathrm{LTC}_{4}$ with histamine and $\mathrm{PGD}_{2}$ in airway calibre in asthma. $J$ Appl Physiol 1989; 66: 304-312.

104. Arm JP, Spur BW, Lee TH. The effects of inhaled leukotriene $\mathrm{E}_{4}$ on the airway responsiveness to histamine in subjects with asthma and normal subjects. J Allergy Clin Immunol 1988; 82: 654-660.

105. Arm JP, O'Hickey SP, Hawksworth RJ, et al. Asthmatic airways have a disproportionate hyperresponsiveness to $\mathrm{LTE}_{4}$ as compared with normal airways, but not to $\mathrm{LTC}_{4}$. $\mathrm{LTD}_{4}$, methacholine and histamine. Am Rev Respir Dis 1990; 142: 1112-1118.

106. Hui KP, Barnes NC. Lung function improvement in asthma with a cysteinyl-leukotriene receptor antagonist. Lancet 1991; 337: 1062-1063.

107. Kips JC, Joos GF, Felman EA, Pauwels RA. The effect of inhaled ICI 204,219 on baseline lung function in moderate asthma. Am Rev Respir Dis 1993; 147 (Suppl
2): A297 (Abstract).

108. Joos GF, Kips JC, Pauwels RA, Van Der Straeten ME. The effect of aerosolized SK\&F 104,353-Z2 on the bronchoconstrictor effect of leukotriene $\mathrm{D}_{4}$ in asthmatics. Pulm Pharmacol 1991; 4: 37-42.

109. Gaddy JN, Margolskee DJ, Bush RK, Williams VC, Busse WW. Bronchodilation with a potent and selective leukotriene $\mathrm{D}_{4}\left(\mathrm{LTD}_{4}\right)$ receptor antagonist (MK-571) in patients with asthma. Am Rev Respir Dis 1992; 146: 358-363.

110. Dahlén B, Margolskee DJ, Zetterstrom O, Dahlen SE. Effect of leukotriene receptor antagonist MK-0679 on baseline pulmonary function in aspirin-sensitive asthmatic subjects. Thorax 1993; 48: 1205-1210.

111. Cloud ML, Enas GC, Kemp J, et al. A specific $\mathrm{LTD}_{4} /$ $\mathrm{LTE}_{4}$-receptor antagonist improves pulmonary function in patients with mild, chronic asthma. Am Rev Respir Dis 1989; 140: 1336-1339.

112. Margolskee D, Bodman S, Dock R, et al. The therapeutic effects of MK-571, a potent and selective leukotriene (LT) $\mathrm{D}_{4}$ receptor antagonist in patients with chronic asthma. J Allergy Clin Immunol 1991; 87: 309. (Abstract).

113. Spector SL, Smith LJ, Glass M. Effects of six weeks of therapy with oral doses of ICI 204,219 , a leukotriene $\mathrm{D}_{4}$, receptor antagonist, in subjects with bronchial asthma. Am J Respir Crit Care Med 1994, 150: 618-623.

114. Wahedna J, Wisniewski AFZ, Wong GS, Tattersfield AE. Effect of multiple doses of RG 12525, an oral leukotriene $\mathrm{D}_{4}$ antagonist in chronic asthma. Am Rev Respir Dis 1992; 145: A16 (Abstract).

115. Gaddy J, Bush RK, Margolskee D, Williams VC, Busse $\mathrm{W}$. The effects of a leukotriene $\mathrm{D}_{4}\left(\mathrm{LTD}_{4}\right)$ antagonist (MK-571) in mild to moderate asthma. J Allergy Clin Immunol 1990; 85: 197A.

116. Wang CG, Du T, Xu LJ, Martin JG. Role of leukotriene $\mathrm{D}_{4}$ in allergen-induced increases in airway smooth muscle in the rat. Am Rev Respir Dis 1993; 148: 413-417.

117. Yeung M, O'Connor SA, Parry DT, Cochrane GM. Compliance with prescribed drug therapy in asthma. Respir Med 1994; 88: 31-35. 